\title{
NEANDERTALCZYK I CZLOWIEK ANATOMICZNIE WSPÓŁCZESNY W UJĘCIU NAJNOWSZYCH ŹRÓDEŁ ARCHEOLOGICZNYCH I PALEOANTROPOLOGICZNYCH
}

\author{
NEANDERTALS AND ANATOMICALLY MODERN HUMANS \\ IN THE RECENT ARCHAEOLOGICAL \\ AND PALAEOANTHROPOLOGICAL RESEARCH
}

\author{
Olga Dec \\ Instytut Archeologii, Uniwersytet Adama Mickiewicza \\ ul. Umultowska 89D, 61-614 Poznań \\ olgadec95@gmail.com
}

\begin{abstract}
The article summarises recent discoveries regarding Neandertals and anatomically modern humans $(\mathrm{AMH})$, and tries to examine currently leading trends in the fields of archaeology and palaeoanthropology. Collected evidence suggests that modern research focuses mostly on discussions on the origin of symbolism, cultural and cognitive capacities, and analyses of ancient DNA. Although archaeology and palaeoanthropology undoubtedly provide the highest number of sources, other sciences such as cognitive neuroscience also deliver new, equally valuable perspectives and information.
\end{abstract}

KEY WORDS: Middle Palaeolithic, Neandertals, anatomically modern humans, symbolism, archaeogenetic

Celem niniejszego artykułu jest przedstawienie wyników najnowszych badań dotyczących neandertalczyków, ludzi anatomicznie współczesnych ${ }^{1}$ oraz ich relacji, a także przedstawienie obecnych kierunków w nauce podejmowanych podczas analiz wyżej wymienionych zagadnień. Kierunki te i badania łączą się z rozwojem

\footnotetext{
${ }^{1} \mathrm{~W}$ celu uniknięcia powtórzeń, autorka od tego miejsca będzie ludzi anatomicznie współczesnych określać również mianem $\mathrm{AMH}$, co stanowi skrót od angielskiego terminu anatomically modern humans.
} 
technologicznym ostatnich lat, który umożliwia przeprowadzanie nie tylko licznych analiz materiału genetycznego, lecz m.in. także datowań oraz rekonstrukcji struktur mózgu. Prezentowane informacje bazują na anglojęzycznej literaturze przedmiotu, ze szczególnym uwzględnieniem publikacji z lat 2017-2018, które ukazały się w czasopismach naukowych.

Poruszana problematyka jest wybitnie inter- i multidyscyplinarna (Henke i Tattersall, 2007, s. vii). Z jednej strony oferuje to wiele możliwych perspektyw, z drugiej - ze względu na mnogość i różnorodność źródeł - może jednak stwarzać pewne problemy przy próbach ujęcia omawianych zjawisk w sposób holistyczny. Zauważalna jest przy tym stała istotna rola analiz materiału genetycznego (Slatkin i Racimo, 2016) oraz zainteresowań i rozważań nad symbolizmem, co z kolei wpisuje się $\mathrm{w}$ dominujące we współczesnym środowisku paleoantropologicznym trendy (Hoffmann i in., 2018).

Dyskurs nad symbolizmem - wymienianym w kontekście między innymi wytwórstwa przedmiotów, sztuki oraz posługiwania się zaawansowanym językiem dotyczy przede wszystkim jego genezy oraz przynależności. Wiąże się to z szerzej zakrojonymi studiami nad neandertalskim potencjałem kulturowym i kognitywnym. O ile bezsprzecznie można przypisywać tworzenie i posługiwanie się symbolami ludziom anatomicznie współczesnym, o tyle niejednoznaczne jest to w przypadku neandertalczyków. Środowisko naukowe podzielone jest w kwestii tego, jak interpretować łączone z neandertalczykami znaleziska, określane jako posiadające znaczenie symboliczne, takie jak: konstrukcje wewnątrz jaskiń (Jaubert i in., 2016), użytkowane pigmenty (Hoffmann i in., 2018b; Zilhão i in., 2010; Bonjean i in., 2015), ozdoby z muszli (Zilhão i in., 2010; Peresani i in., 2013), pazurów i kości ptaków (Radovčić i in., 2015; Majkić i in., 2017) czy sztuka (Rodríguez-Vidal i in., 2014; Hoffmann i in., 2018a). Brak konsensusu widoczny jest tym bardziej przy określaniu stopnia neandertalskiego potencjału poznawczego. Potwierdzają to chociażby głosy odnotowane i przytoczone przez T. Appenzellera (2018) w kontekście odkryć (rzekomo) neandertalskiej sztuki naskalnej w Hiszpanii.

Najwięcej źródeł do refleksji nad podejmowanym w niniejszym artykule temacie dostarcza archeologia. Wśród tych źródeł wymienia się między innymi: złożoność technologii wytwórstwa narzędzi (Dediu i Levinson, 2018; Aranguren i in., 2018; Majkić i in., 2018; Lind i in., 2013), dziegciarstwo (Kozowyk i in., 2017), wykorzystanie roślin o właściwościach leczniczych (Weyrich i in., 2017), sposoby odżywiania się (Gómez-Olivencia i in., 2018), a także wspomniane wyżej używanie pigmentów, muszli oraz pazurów i kości ptaków do wyrobu przedmiotów interpretowanych jako symboliczne lub ozdobne. Intencjonalne tworzenie tego typu przedmiotów, a także sztuki jest przejawem abstrakcyjnego myślenia. Chociaż tworzenie sztuki naskalnej uznawano za jedną $\mathrm{z}$ charakterystycznych różnic między neandertalczykami a AMH, gdzie to ci drudzy mieli być jej pierwszymi autorami, od pewnego czasu znane są przykłady stanowisk archeologicznych, które przypisuje się 
neandertalczykom. Za takie uznaje się petroglify z jaskini Gorhama na Gibraltarze (Rodríguez-Vidal i in., 2014) oraz odciski z El Castillo, chociaż te równie dobrze można przypisywać ludziom anatomicznie współczesnym, biorąc pod uwagę niejednoznaczność danych (Hoffmann i in., 2018a).

W roku 2018 opublikowane zostały wyniki datowań malowideł naskalnych jaskiń La Pasiega, Maltravieso i Ardales. Badania dowiodły, że w kontekście Półwyspu Iberyjskiego można mówić o najstarszych przypadkach sztuki naskalnej, którą dodatkowo należałoby wiązać właśnie z populacjami neandertalskimi. Daty z La Pasiegi, Maltravieso i Ardales, uzyskane na drodze datowań metodą uranowo-torową, wykazały, że poddane analizom malowidła pochodzą sprzed około 64,8 tys. lat (Hoffmann i in., 2018a). Mając na względzie, że obecny stan wiedzy pozwala sądzić, że do Europy ludzie anatomicznie współcześni dotarli około 40 tys. lat temu, a na pewno nie wcześniej niż 45 tys. lat temu (Villa i in., 2018; Hoffmann i in., 2018a; Benazzi i in., 2015; Higham i in., 2011), według autorów przeprowadzonych badań przyjmować należy neandertalskie pochodzenie omawianych malowideł. Doniesienia o tak rewolucyjnym charakterze (Appenzeller, 2018) spotkały się z głosami krytyki. Chociażby w opinii Pearce’a i Bonneau (2018) wątpliwości budzą szerokie ramy, w których zawarły się uzyskane datowania. Aubert i in. (2018) z kolei wskazali na brak wyjaśnień co do pochodzenia datowanych znaków, zwracając uwagę na ich możliwą naturalną genezę na skutek działań mikroorganizmów lub tlenków zawartych w sedymentach.

Refleksje w kontekście zdolności poznawczych neandertalczyków prowadzone są również w ramach neuronauki i kognitywistyki. Analizom oraz próbom rekonstrukcji poddawana jest budowa mózgu. Wyniki uzyskane na drodze tych rekonstrukcji, po porównaniu z mózgami ludzi anatomicznie współczesnych, wykazują pewną prawidłowość, o której już wcześniej wspominał chociażby Pearce i in. (2013). Neandertalskie mózgi najprawdopodobniej miały większych rozmiarów obszary płata potylicznego ${ }^{2}$, podczas gdy mózgi AMH charakteryzowały większe półkule móżdżku (Kochiyama i in., 2018). Zespół badaczy zwrócił uwagę na to, że móżdżek odpowiada między innymi za zdolności kognitywne, myślowe oraz funkcje społeczne, wśród których wymienia się między innymi stopień przetwarzania języka. Pod tym pojęciem Kochiyama i in. rozumieją zdolność do wytwarzania i rozumienia dźwięków i znaków, co umożliwia komunikację między jednostkami. $\mathrm{W}$ oryginale Language processing refers to the ability to produce and comprehend sounds and signs, which enables shared communication between individuals (Kochiyama $\mathrm{i}$ in., 2018).

\footnotetext{
${ }^{2}$ Większy rozmiar płata potylicznego u neandertalczyków ma być powiązany z większymi rozmiarami oczu, jako że odpowiada m.in. za wzrok. Większe oczy thumaczone są dostosowaniem do mniejszych ilości światła i mniejszego nasłonecznienia występującego na szerokościach geograficznych zamieszkiwanych przez neandertalczyków (Pearce i in., 2013; Kochiyama i in., 2018).
} 
Zagadnienia dotyczące tego, czy neandertalczycy posługiwali się artykułowaną mową, stanowią kolejny wątek w dyskursie nad zdolnościami poznawczymi. O ile sama zdolność neandertalczyków do mówienia została potwierdzona (D’Anastasio i in., 2013), o tyle nie równa się ona automatycznie językowi (Lind i in., 2013). Bazując na źródłach dotyczących neandertalskich wyrobów oraz potwierdzonych zachowań, m.in. D. Dediu i S. C. Levinson (2018) uznali, że złożoność niektórych tych elementów wymaga znajomości języka w stopniu pozwalającym na swobodną wymianę informacji oraz przekazywanie wiedzy. Język z kolei, jak sugerują D. L. Hoffmann, D. E. Angeluci, V. Villaverde, J. Zapata i J. Zilhão, zdaje się wiązać z rozumieniem i wykorzystywaniem wspomnianych wcześniej w artykule symboli. Biorąc pod uwagę wszystkie przykłady posługiwania się przez neandertalczyków iberyjskich przedmiotami interpretowanymi jako symboliczne, wymienieni badacze proponują więc teorię, w myśl której początki zarówno języka, jak i zaawansowanych procesów kognitywnych mogą sięgać ponad 500 tys. lat wstecz (Hoffmann i in., 2018b).

Chociaż nie nawiązuje to tematycznie do poruszanych wcześniej problemów, istotne wydaje się przytoczenie badań potwierdzających obecność neandertalczyków na nowych terenach i w nowych kontekstach. Mimo że obszar Półwyspu Iberyjskiego ma szeroko udokumentowaną i zaadresowaną w literaturze przedmiotu historię występowania stanowisk i szczątków neandertalskich, wciąż odkrywane są nowe znaleziska. Dzięki analizom opublikowanym w 2018 r. po raz pierwszy wykazano obecność szczątków neandertalskich w ramach kontekstu stratygraficznego w hiszpańskiej Sierra de Atapuerca (Pablos i in., 2018). W tym samym roku do wiadomości publicznej podane zostało inne odkrycie o podobnym charakterze - dotyczyło ono znalezienia fragmentów kości neandertalskiego dziecka w Jaskini Ciemnej (gm. Skała, woj. małopolskie). Odkryte w Polsce południowej neandertalskie szczątki są w chwili obecnej najstarszymi szczątkami ludzkimi na obszarze całego kraju ${ }^{3}$.

W przypadku ludzi anatomicznie współczesnych (oprócz omawianego wcześniej symbolizmu) podejmowany jest dodatkowo temat ich pojawienia się oraz rozprzestrzenienia. Przez długi czas utrzymywano, że kolebką naszego gatunku jest Afryka Wschodnia. Wówczas najstarsze szczątki wczesnych form Homo sapiens sapiens znane były ze stanowisk etiopskich, to jest z Omo Kibish i z Herto Bouri, i datowane były kolejno na 195 tys. i 160 tys. lat. Nie jest to jednak już tak jednoznaczne. Obecnie najstarsze znane pozostałości wczesnych AMH pochodzą wcale nie ze wschodu, lecz z północy afrykańskiego kontynentu, z Dżabal Irhoud położonego w pobliżu Safi w Maroku. Odkryte tam szczątki datowane są według najnowszych

\footnotetext{
${ }^{3}$ Ze względu na to, że w chwili pisania niniejszego artykułu publikacja odnosząca się do wspominanego tematu nie jest jeszcze dostępna, autorka artykułu pozwoliła sobie powołać się na informacje podawane przez Polską Agencję Prasową. Pobrano z: http://naukawpolsce.pap.pl/aktualnosci/news\% 2C31267\%2Codkryto-najstarsze-szczatki-czlowieka-w-polsce-maja-ponad-100-tys-lat.html
} 
badań na $315 \pm 34$ tys. lat (Hublin i in., 2017). Mimo zmian co do myślenia na temat dokładnego miejsca powstania gatunku, niezmiennie pozostaje nim szeroko pojmowana Afryka.

Drugim elementem wyżej wspomnianych refleksji obok problematyki powstania gatunku jest zagadnienie jego wyjścia z Afryki. Bazując na rozłożeniu geograficznym znalezisk powiązanych ze wczesnymi Homo sapiens, aktualnie najbardziej prawdopodobną linią rozprzestrzeniania się ludzi anatomicznie współczesnych stanowi droga przez Lewant. Z Izraela pochodzą bowiem szczątki, które są interpretowane jako najstarsze ze wszystkich tych, które znajdują się poza Afryką. W $2018 \mathrm{r}$. zespół I. Hershkovitza (Hershkovitz i in., 2018) opublikował wyniki datowań fragmentu szczęki, określanego jako Misliya-1 i wydobytego z izraelskiej jaskini Misliya. Według badaczy analizowane przez nich szczątki należą do przedstawiciela Homo sapiens i pochodzą sprzed 177-194 tys. lat, co ma być tym samym dowodem na wcześniejsze niż dotychczas podejrzewano wyjście AMH z Afryki.

Zaprezentowane przez I. Hershkovitza i in. wyniki doczekały się jednak krytyki sugerującej, że wysnute wnioski oraz datowania bazowały na błędnej interpretacji zanieczyszczonych próbek, co tym samym podważa wiarygodność samego znaleziska (Sharp i Paces, 2018). W z dużą dozą prawdopodobieństwa przyjmować należy, że chociaż najstarsze dowody na obecność AMH poza Afryką rzeczywiście pochodzą z terenu Lewantu, to dotyczą okresu sprzed około 90-120 tys. lat i stanowią szczątki Shkul i Qafzeh (Sharp i Paces, 2018; Lamb i in., 2018).

$\mathrm{Na}$ terenach Lewantu miało też dojść najprawdopodobniej do kontaktu AMH z neandertalczykami. Przemawiają za tym badania genetyczne skupiające się na przepływie genów między dwiema wspomnianymi grupami i omawiające zagadnienie krzyżowania, do którego między nimi dochodziło, co zostało już wielokrotnie potwierdzone ponad wszelką wątpliwość licznymi badaniami (Neves i Serva, 2012; Wall i in., 2013; Fu i in., 2014, 2015, 2016; Prüfer i in., 2014; Kuhlwilm i in., 2016; Slatkin i Racimo, 2016; Gregory i in., 2017; Nielsen i in., 2017; Simonti i in., 2016; Slon i in., 2017, 2018; Browning i in., 2018).

Mimo tak mnogich dowodów na krzyżowanie, do tej pory nie udało się znaleźć lub zidentyfikować szczątków, które można byłoby jednoznacznie interpretować jako hybrydę neandertalczyka i AMH. Inaczej ma się sytuacja relacji neandertalsko-denisowskich. Denisowianie (także: ludzie z jaskini Denisowej) to rodzaj pokrewny zarówno neandertalczykom, jak i ludziom anatomicznie współczesnym, chociaż zdecydowanie bliższe więzy krwi łączą ich z tymi pierwszymi (Posth i in., 2017). Mimo bardzo nielicznych znalezisk wiązanych z tymi homininami, odkrytymi po raz pierwszy w 1984 r. w jaskini w Ałtaju na południu Syberii, na które składa się jedynie kilka fragmentów zębów trzonowych oraz kości (Slon i in., 2017; Stringer i Barnes, 2015; Reich i in., 2010; Krause i in. 2010; Brown i in., 2016). Chociaż, jak na tę chwilę, wszystkie znaleziska pochodzą z tej samej rosyjskiej jaskini, badania genetyczne sugerują, że niegdyś denisowianie mogli zamieszkiwać znacznie większe 
regiony świata (Meyer i in., 2016); dokładny obszar jednak z oczywistych powodów pozostaje na razie nieznany.

Analizy genomu osobnika Denisova 11 wykazały, że jest to hybryda, której matka była neandertalczykiem, a ojciec denisowianinem (Slon i in., 2018). W przypadku hybryd neandertalczyka i Homo sapiens najbliższym znanym stopniem takiego pokrewieństwa odznaczają się na tę chwilę szczątki Oase 1 (Slon i in., 2018; Fu i in., 2015). Odnalezione w 2002 r. (Trinkaus i in., 2003) w jaskini Peștera cu Oase położonej w południowo-zachodniej Rumunii niedaleko Aniny - miasta między parkami narodowymi Semenic-Cheile Carașului i Nerei-Beușnița - mają według szacunków około 6-9\% genomu pochodzenia neandertalskiego. To z kolei sugeruje, że Oase $1 \mathrm{i}$ jego neandertalskiego przodka dzieli od czterech do sześciu pokoleń (Fu i in., 2015).

Obraz, jaki wyłania się na podstawie zgromadzonych informacji, przedstawia się następująco:

- Niezmienione pozostają dotychczasowe ustalenia co do okresu występowania neandertalczyków, przy czym tereny, na których potwierdzona została ich obecność, rozszerzyć można o Polskę południową. Dodatkowo obecność neandertalska potwierdzona jest w kontekstach stratygraficznych dla Sierra de Atapuerca. Nowe informacje w zakresie badań nad neandertalczykami dotyczą przede wszystkim zdolności poznawczych: wytwarzania przedmiotów o charakterze symbolicznym, tworzenia sztuki naskalnej, a także budowy oraz organizacji mózgów (Hoffmann i in., 2018a, 2018b; Pearce i Bonneau, 2018; Aubert i in., 2018; Dediu i Levinson, 2018; Aranguren i in., 2018; Majkić i in., 2018; Pablos i in., 2018; Gómez-Olivencia i in., 2018; Kochiyama i in., 2018; Majkić i in., 2017; Kozowyk i in., 2017; Weyrich i in., 2017; PAP, http://na ukowawpolsce.pap.pl/...);

- Przesunięta została dolna granica pojawienia się Homo sapiens: ze 190 tys. do na około 315 tys. lat temu. Te same badania dowiodły, że najstarsze szczątki ludzi anatomicznie współczesnych pochodzą nie z Afryki Wschodniej (Etiopia), lecz Północno-Zachodniej (Maroko). Przedstawione zostały datowania wskazujące także na wcześniejszy, niż dotychczas sądzono moment pojawienia się AMH poza Afryką, tj. na terenie Lewantu. Mając na względzie krytykę, sugerującą, że owe badania opierały się na niewłaściwych próbkach, informacje te przyjmować należy z ostrożnością (Hershkovitz i in., 2018; Sharp i Paces, 2018; Lamb i in., 2018; Hublin i in., 2018);

- Informacje co do krzyżowania się neandertalczyków i ludzi anatomicznie współczesnych nie uległy zmianie. Odkrycia poczynione zostały natomiast w zakresie relacji neandertalczyków i denisowian. Potwierdzone zostało istnienie szczątków osobnika będącego w połowie neandertalczykiem, w połowie denisowianinem (osobnik Denisova 11). Jest to tym samym pierwszy znany i potwierdzony przykład hybrydy dwóch gatunków człowieka (Slon i in., 2018). 
Pamiętać jednak należy, że artykuł ten - choćby ze względu na bariery językowe - nie obejmuje wszystkich dostępnych źródeł, które ukazały się w ostatnich dwóch latach. Mimo wszystko zdaniem autorki, bazując na przedstawionym materiale, można zauważyć dynamiczny rozwój zasobu wiadomości w kontekście rozpatrywanej problematyki.

Dostrzegalna jest przy tym tendencja do podejmowania zagadnień symboliki, która z kolei mieści się w ramach szerszej kategorii, jaką jest zdolność kognitywna i kulturowa. Jest to przede wszystkim widoczne w przypadku rozważań nad neandertalczykami. Powodem tego wydaje się być rozłam wśród badaczy, u podłoża którego leży trwający od lat dyskurs dotyczący neandertalskiego potencjału umysłowego i kulturowego. Podczas gdy jedni badacze stawiają w tym aspekcie znak równości między neandertalczykami a $\mathrm{AMH}$, inni są sceptyczni co do twierdzeń o ich równorzędności.

Mając na uwadze wielogłosowość nauki w zakresie omawianych rozważań i badań, z dużą dozą prawdopodobieństwa można przyjąć, że w przypadku neandertalczyków mówić można o rozwiniętych zdolnościach kulturowych i poznawczych. Kwestią sporną pozostaje jednak określenie stopnia owego rozwinięcia, szczególnie w kontekście porównywania go do tego prezentowanego przez AMH. Tym samym istotne zdaje się dokładne śledzenie doniesień zarówno z zakresu poruszanego w niniejszym artykule tematu, jak i tematów mu pokrewnych.

\section{BIBLIOGRAFIA}

Appenzeller, T.

2018 Europe's first artists were Neandertals. Science, 359, 852-853.

Aranguren, B., Revedin, A., Amico, N., Cavulli, F., Giachi, G., Grimaldi, S., Macchoni, N., Santaniello, F.

2018 Wooden tools and fire technology in the early Neanderthal site of Poggetti Vecchi (Italy). Proceedings of the National Academy of Sciences. DOI: 10.1073/pnas.1716068115

Aubert, M., Brumm, A., Huntley, J.

2018 Early dates for 'Neanderthal cave art' may be wrong. Journal of Human Evolution. DOI: 10.1016/j.jhevol.2018.08.004 [artykuł w druku]

Benazzi, S., Slon, V., Talamo, S., Negrino, F., Peresani, M., Bailey, S. E., Sawyer, S., Panetta, D., Vicino, G., Starnini, E., Mannino, M. A., Salvadori, P. A., Meyer, M., Pääbo, S., Hublin, J.-J.

2015 The makers of the Protoaurignacian and implications for Neandertal extinction. Science, 348, 792-795.

Bonjean, D., Vanbrabant, Y., Abrams, G., Pirson, S., Burlet, C., Di Modica, K., Otte, M., Auwera, J. V., Golitko, M., McMillan, R., Goemaere, E.

2015 A new Cambrian black pigment used during the late Middle Palaeolithic discovered at Scladina Cave (Andenne, Belgium). Journal of Archaeological Science, 55, 253-265.

Brown, S., Higham, T., Slon, V., Pääbo, S., Meyer, M., Douka, K., Brock, F., Comeskey, D., Procopio, N., Shunkov, M., Derevianko, A., Buckley, M.

2016 Identification of a new hominin bone from Denisova Cave, Siberia using collagen fingerprinting and mitochondrial DNA analysis. Scientific Reports, 6, 23559. DOI: $10.1038 /$ srep23559 
Browning, S. R., Browning, B. L., Zhou, Y., Tucci, S., Akey, J. M.

2018 Analysis of Human Sequence Data Reveals Two Pulses of Archaic Denisovan Admixture. Cell, 173, 53-61.

D’Anastasio, R., Wroe, S., Tuniz, C., Mancini, L., Cesana, D. T., Dreossi, D., Ravichandiran, M., Attard, M., Parr, W. C. H., Agur, A., Capasso, L.

2013 Micro-Biomechanics of the Kebara 2 Hyoid and Its Implications for Speech in Neanderthals. PLoS ONE, 8(12), e82261. DOI: 10.1371/journal.pone.0082261

Dec, O.

2017 Neandertalczyk $i$ człowiek anatomicznie wspótczesny w ujęciu najnowszych źródet archeologicznych i paleoantropologicznych [Maszynopis pracy licencjackiej, Instytut Archeologii Uniwersytetu im. Adama Mickiewicza w Poznaniu].

Dediu, D., Levinson, S. C.

2018 Neanderthal language revisited: not only us. Current Opinion in Behavioral Sciences, $21,49-55$.

Fu, Q., Hajdinjak, M., Moldovan, O. T., Constantin, S., Mallick, S., Skoglund, P., Patterson, N., Rohland, N., Lazaridis, I., Nickel, B., Viola, B., Prüfer, K., Meyer, M., Kelso, J., Reich, D., Pääbo, $\mathrm{S}$.

2015 An early modern human from Romania with recent Neanderthal ancestor. Nature, 524, 216-219.

Fu, Q., Li, H., Moorjani, P., Jay, F., Slepchenko, S. M., Bondarev, A. A., Johnson, P. L. F., Aximu-Petri, A., Prüfer, K., Filippo, C. de, Meyer, M., Zwyns, N., Salazar-García, D. C., Kuzmin, Y. V., Keates, S. G., Kosintsev, P. A., Razhev, D. I., Richards, M. P., Peristov, N. V., Lachmann, M., Douka, K., Higham, T. F. G., Slatkin, M., Hublin, J.-J., Reich, D., Kelso, J., Viola, T. B., Pääbo, S.

2014 Genome sequence of a 45,00-year-old modern human from western Siberia. Nature, 514, 445-449.

Fu, Q., Posth, C., Hajdinjak, M., Petr, M., Mallick, S., Fernandes, D., Furtwängler, A., Haak, W., Meyer, M., Mittnik, A., Nickel, B., Peltzer, A., Rohland, N., Slon, V., Talamo, S., Lazardis, I., Lipson, M., Mathieson, I., Schiffels, S., Skoglund, P., Derevianko, A. P., Drozdov, N., Slavinsky, V., Tsybankov, A., Cremonesi, R. G., Mallegni, F., Gély, B., Vacca, E., Morales, M. R. G., Straus, L. G., Neugebauer-Maresch, C., Teschler-Nicola, M., Constantin, S., Moldovan, O. T., Benazzi, S., Peresani, M., Coppola, D., Lari, M., Ricci, S., Ronchitelli, A., Valentin, F., Thevenet, C., Wehrberger, K., Grigorescu, D., Rougier, H., Crevecoeur, I., Flas, D., Semal, P., Mannino, M. A., Cupillard, C., Bocherens, H., Conrad, N. J., Harvati, K., Moiseyev, V., Drucker, D. G., Svoboda, J., Richards, M. P., Caramelli, D., Pinhasi, R., Kelso, J., Patterson, N., Krause J., Pääbo, S., Reich, D.

2016 The genetic history of Ice Age Europe. Nature, 534, 200-205.

Gómez-Olivencia, A., Sala, N., Núñez-Lahuerta, C., Sanchis, A., Arlegi, M., Rios-Garaizar, J.

2018 First data of Neandertal bird and carnivore exploitation in the Cantabrian Region (Axlor, Barandiaran excavations, Dima, Biscay, Northern Iberian Peninsula). Scientific Reports, 8, 10551. DOI: 10.1038/s41598-018-28377-y

Gregory, M. D., Kippelhan, J. S., Eisenberg, D. P., Kohn, P. D., Dickinson, D., Mattay, V. S., Chen, Q., Weinberger, D. R., Saad, Z. S., Berman, K. F.

2017 Neanderthal-Derived Genetic Variation Shapes Modern Human Cranium and Brain. Scientific Reports. DOI: 10.1038/s41598-017-06587-0

Henke, W., Tattersall, I.

2007 Handbook of Paleoanthropology. New York, NY: Springer.

Higham, T., Comptin, T., Stringer, C., Jacobi, R., Shapiro, B., Trinkaus, E., Chandler, B., Gröning, F., Collins, C., Hillson, S., O'Higgins, P., FitzGerald, C., Fagan, M. 
2011 The earliest evidence for anatomically modern humans in northwestern Europe. Nature, 479, 521-524.

Hoffman, D. L., Standish, C. D., García-Diez, M., Pettitt, P. B., Milton, J. A., Zilhão, J., Alcolea-González, J. J., Cantalejo-Duarte, P., Collado, H., Balbín, R. de, Lorblanchet, M., Ramos-Muñoz, J., Weniger, G.-Ch., Pike, A. W. G.

2018a U-Th dating of carbonate crusts reveals Neandertal origin of Iberian cave art. Science, 359, 912-915.

Hoffmann, D. L., Angeluci, D. E., Villaverde, V., Zapata, J., Zilhão, J.

$2018 \mathrm{~b}$ Symbolic use of marine shells and mineral pigments by Iberian Neandertals 115,000 years ago. Science Advances, 4(2), eaar 5255.

Hublin, J.-J., Ben-Ncer, A., Bailey, S. E., Freidline, S. E., Neubauer, S., Skinner, M. M., Bergmann, I., Le Cabec, A., Benazzi, S., Harvati, K., Gunz, P.

2017 New fossils from Jebel Irhoud, Morocco and the pan-African origin of Homo sapiens. Nature, 546, 289-292.

Jaubert, J., Verheyden, S., Genty, D., Soulier, M., Cheng, H., Blamart, D., Burlet, C., Camus, H., Delaby, S., Deldicque, D., Edwards, R. L., Ferrier, C., Lacrampe-Cuyaubère, F., Lévêque, F., Maksud, F., Mora, P., Muth, X., Régnier, É., Rouzad, J.-N., Santos, F.

2016 Early Neanderthal constructions deep in Bruniquel Cave in southwestern France. Nature, $534,111-114$.

Kochiyama, T., Ogihara, N., Tanabe, H. C., Kondo, O., Amano, H., Hasegawa, K., Suzuki, H., Ponce de León, M. S., Zollikofer, C. P. E., Bastir, M., Stringer, C., Sadato, N., Akazawa, T.

2018 Reconstructing the Neanderthal brain using computational anatomy. Scientific Reports, 8, 6296. DOI: $10.1038 / \mathrm{s} 41598-018-24331-0$

Kozowyk, P. R. B., Soressi, M., Pomstra, D., Langejans, G. H. J.

2017 Experimental methods for the Palaeolithic dry distillation of birch bark: implications for the origin and development of Neandertal adhesive technology. Scientific Reports, 7, 8033. DOI: $10.1038 / \mathrm{s} 41598-017-08106-7$

Krause, J., Fu, Q., Good, J. M., Viola, B., Shunkov, M. V., Derevianko, A. P., Pääbo, S.

2010 The complete mitochondrial DNA genome of an unknown hominin from southern Siberia. Nature, 464, 894-897.

Kuhlwilm, M., Gronau, I., Hubisz M. J., Filippo, C. de, Prado-Martinez, J., Kircher, M., Fu, Q., Burbano, H. A., Lalueza-Fox, C., Rasilla, M. de la, Rosas, A., Rudan, P., Brajkovic, D., Kucan, Ž., Gušic I., Marques-Bonet, T., Andrés, A. M., Viola, B., Pääbo, S., Meyer, M., Siepel, A., Castellano, S.

2016 Ancient gene flow from early modern humans into Eastern Neanderthals. Nature, 530, 429-433.

Lamb, H. F., Bates, C. R., Bryant, C. L., Davies, S. J., Huws, D. G., Marshall, M. H., Roberts, H. M.

2018 150,000-year palaeoclimate record from northern Ethiopia supports early, multiple dispersals of modern humans from Africa. Scientific Reports, 8, 1077. DOI: 10.1038/ s41598-018-19601-w

Lind, J., Lindenfors, P., Ghirlanda, S., Lidén, K., Enquist, M.

2013 Dating human cultural capacity using phylogenetic principles. Scientific Reports, 3. DOI: $10.1038 /$ srep01785

Majkić, A., D’Errico, F., Stepanchuk, V.

2018 Assessing the significance of Palaeolithic engraved cortexes. A case study from the Mousterian site of Kiik-Koba, Crimea. PLoS ONE, 13(5), e0195049.

Majkić, A., Evans, S., Stepanchuk, V., Tsvelykh, A., D’Errico, F.

2017 A decorated raven bone from the Zaskalnaya VI (Kolosovskaya) Neanderthal site, Crimea. PLoS ONE, 12(03), e0173435. DOI: 10.1371/journal.pone.0173435 
Meyer, M., Arsuaga, J.-L., Filippo, C. de, Nagel, S., Aximu-Petri, A., Nickel, B., Martínez, I., Gracia, A., Castro, J. M. B. de, Carbonell, E., Viola, B., Kelso, J., Prüfer, K., Pääbo, S.

2016 Nuclear DNA sequences from the Middle Pleistocene Sima de los Huesos hominins. Nature, 531, 504-507.

Neves, A., Serva, M.

2012 Extremely Rare Interbreeding Events Can Explain Neanderthal DNA in Living Humans. PLoS ONE, 7(10), e47076. DOI: 10.1371/journal.pone.0047076

Nielsen, R., Akey, J. M., Jakobsson, M., Pritchard, J. K., Tishkoff, S., Willerslev, E.

2017 Tracing the peopling of the world through genomics. Nature, 541, 302-310.

Pablos, A., Gómez-Olivencia, A., Arsuaga, J. L.

2018 A Neandertal foot phalanx from the Galería de las Estatuas site (Sierra de Atapuerca, Spain). American Journal of Physical Anthropology. DOI: 10.1002/ajpa.23729

Polska Agencja Prasowa, Odkryto najstarsze szczatki człowieka w Polsce; maja ponad 100 tys. lat. Pobrano z: http://naukawpolsce.pap.pl/aktualnosci/news\%2C31267\%2Codkryto-najstar sze-szczatki-czlowieka-w-polsce-maja-ponad-100-tys-lat.html

Posth, C., Wißing, C., Kitagawa, K., Pagani, L., Holstein, L., Racimo, F. van, Wehrberger, K., Conrad, N. J., Kind, C. J., Bocherens, H., Krause, J.

2017 Deeply divergent archaic mitochondrial genome provides lower time boundary for African gene flow into Neanderthals. Nature Communications, 8, 16046. DOI: 10.1038/ ncomms 16046

Prüfer, K., Racimo, F., Patterson, N., Jay, F., Sankararaman, S., Sawyer, S., Heinze, A., Renaud, G., Sudmant, P. H., Filippo, C. de, Li, H., Mallick, S., Dannemann, M., Fu, Q., Kircher, M., Kuhlwilm, M., Lachmann, M., Meyer, M., Ongyerth, M., Siebauer, M., Theunert, C., Tandon, A., Moorjani, P., Pickrell, J., Mullikin, J. C., Vohr, S. H., Green, R. E., Hellmann, I., Johnson, P. L. F., Blanche, H., Cann, H., Kitzman, J. C., Shendure, J., Eichler, E. E., Lein, E. S., Bakken, T. E., Golovanova, L. V., Doronichev, V. B., Shunkov, M. V., Derevianko, A. P., Viola, B., Slatkin, M., Reich, D., Kelso, J., Pääbo, S.

2014 The complete genome sequence of a Neanderthal from the Altai Mountains. Nature, 505, 43-48.

Reich, D., Green, R. E., Kircher, M., Krause, J., Patterson, N., Durand, E. Y., Viola, B., Briggs, A. W., Stenzel, U., Johnson, P. L. F., Maricic, T., Good, J. M., Marques-Bonet, T., Alkan, C., Fu, Q., Mallick, S., Li, H., Meyer, M., Eichler, E. E., Stoneking, M., Richards, M., Talamo, S., Shunkov, M. V., Derevianko, A. P., Hublin, J.-J., Kelso, J., Slatkin, M., Pääbo, S.

2010 Genetic history of an archaic hominin group from Denisova Cave in Siberia. Nature, $468,1053-1060$.

Sharp, W. D. i Paces, J. B.

2018 Comment on „The earliest modern humans outside Africa”. Science, 362. DOI: 10.1126/science.aat6598

Simonti, C., Vernot, B., Bastarache, L., Bottinger, E., Carrell, D. S., Chisholm, R. L., Crosslin, D. R., Hebbring, S. J., Jarvik, G. P., Kullo, I. J., Li, R., Pathak, J., Ritchie, M. D., Roden, D. M., Verma, S. S., Tromp, G., Prato, J. D., Bush, W. S., Akey, J. M., Denny, J. C., Capra, J. A.

2016 The phenotypic legacy of admixture between modern humans and Neandertals. Science, $351,737-741$.

Slatkin, M., Racimo, F.

2016 Ancient DNA and human history. Proceedings of the National Academy of Sciences, $113,6380-6387$. 
Slon, V., Mafessoni, F., Vernot, B., Filippo, C. de, Grote, S., Viola, B., Hajdinjak, M., Peyrégne, S., Nagel, S., Brown, S., Douka, K., Higham, T., Kozlikin, M. B., Shunkov, M. V., Derevianko, A. P., Kelso, J., Meyer, M., Prüfer, K., Pääbo, S.

2018 The genome of the offspring of a Neanderthal mother and a Denisovan father. Nature, $561,113-116$.

Slon, V., Mafessoni, F., Vernot, B., Filippo, C. de, Grote, S., Viola, B., Hajdinjak, M., Peyrégne, S., Nagel, S., Brown, S., Douka, K., Higham, T., Kozlikin, M. B., Shunkov, M. V., Derevianko, A. P., Kelso, J., Meyer, M., Prüfer, K., Pääbo, S.

2018 The genome of the offspring of a Neanderthal mother and a Denisovan father. Nature, $561,113-116$.

Slon, V., Viola, B., Renaud, G., Gansauge. M.-T., Benazzi, S., Sawyer, S., Hublin, J.-J., Shunkov, M. V., Derevianko, A. P., Kelso, J., Prüfer, K., Meyer, M., Pääbo, S.

2017 A fourth Denisovan individual. Science Advances, 3(7), e1700186.

Stringer, C. B., Barnes, I.

2015 Deciphering the Denisovans. Proceedings of the National Academy of Sciences, 112, 15542-15543.

Villa, P., Pollarolo, L., Conforti, J., Mara, F., Biagioni, C., Degano, I., Lucejko, J. J., Tozzi, C., Pennacchioni, M., Zanchetta, G., Nicosia, C., Martini, M., Sibilia, E., Panzeri, L.

2018 From Neandertals to modern humans: New data on the Uluzzian. PLoS ONE, 13(5), e0196786. DOI: 10.1371/journal.pone.0196786

Wall, J. D., Yang, M. A., Jay, F., Kim, S. K., Durand, E. Y., Stevison, L. S., Gignoux, C., Woerner, A., Hammer, M. F., Slatkin, M.

2013 Higher levels of Neanderthal ancestry in East Asians than in Europeans. Genetics. DOI: 10.1534/genetics.112.148213

Weyrich, L. S., Duchene, S., Soubrier, J., Arriola, L., Llamas, B., Breen, J., Morris, A. G., Alt, K. W., Caramelli, D., Dresely, V., Farrell, M., Farrer, A. G., Francken, M., Gully, N., Haak, W., Hardy, K., Harvati, K., Held, P., Holmes, E. C., Kaidonis J., Lalueza-Fox, C., Rasilla, M. de la, Rosas, A., Semal, P., Soltysiak, A., Townsend, G., Usai. D., Wahl. J., Huson, D. H., Dobney, K., Cooper, A.

2017 Neanderthal behaviour, diet, and disease inferred from ancient DNA in dental calculus. Nature, 544, 357-361.

Yotova, V., Lefebvre, J.-F., Moreau, C., Gbeha, E., Hovhannesyan, K., Bourgeois, S., Bédarida, S., Azevedo, L., Amorim, A., Sarkisian, T., Avogbe, P. H., Chabi, N., Dicko, M. H., Amouzou, E. S. K. S., Sanni, A., Roberts-Thomson, J., Boettcher, B., Scott, R. J., Labuda, D.

2017 An X-Linked Haplotype of Neandertal Origin Is Present Among All Non-African Populations. Molecular Biology and Evolution, 28, 1957-1962.

\title{
NEANDERTALS AND ANATOMICALLY MODERN HUMANS IN THE RECENT ARCHAEOLOGICAL AND PALAEOANTHROPOLOGICAL RESEARCH
}

\author{
S u m m a r y
}

In this paper author summarised recent discoveries regarding Neandertals and anatomically modern humans. Another point was made in terms of examination of currently leading trends in this field of research. Based on the collected evidence it was suggested that as of now, research on 
Neandertals focuses mostly on discussions on symbolism, and cultural and cognitive capacities. Genetic analyses of fossil record, as well as various methods of dating both skeletal remains and remains such as carbonate crusts of cave art, are also quite popular. Discoveries that are being made are diverse, stemming from a multidisciplinary background that involves not only archaeology and palaeoanthropology (although these are the two leading sciences that deliver the greatest amount of sources) but also e.g. psychology and cognitive neuroscience. 